Article

\title{
Assessment of Mineral and Phenolic Profiles and Their Association with the Antioxidant, Cytotoxic Effect, and Antimicrobial Potential of Lycium chinense Miller
}

\author{
Muthu Thiruvengadam ${ }^{1} \oplus$, Bimal Kumar Ghimire ${ }^{1}$, Seung-Hyun Kim ${ }^{1}$, Chang Yeon Yu ${ }^{2}$, \\ Deog-Hwan Oh ${ }^{3}$, Ramachandran Chelliah ${ }^{3}$, Chang Kwon ${ }^{1}$, Yun-Ju Kim ${ }^{1}$ and Ill Min Chung ${ }^{1, *}$ \\ 1 Department of Crop Science, College of Sanghuh Life Science, Konkuk University, Seoul 05029, Korea; \\ thiruv30@gmail.com (M.T.); bimal_g12@yahoo.com (B.K.G.); kshkim@konkuk.ac.kr (S.-H.K.); \\ bks12381@gmail.com (C.K.); suluvisu@gmail.com (Y.-J.K.) \\ 2 Bioherb Research Institute, Kangwon National University, Chuncheon 24341, Korea; cyyu@kangwon.ac.kr \\ 3 Food Science and Biotechnology, Kangwon National University, Chuncheon 24341, Korea; \\ deoghwa@kangwon.ac.kr (D.-H.O.); ramachandran865@gmail.com (R.C.) \\ * Correspondence: imcim@konkuk.ac.kr; Tel.: +82-010-547-08301
}

Received: 10 July 2020; Accepted: 7 August 2020; Published: 13 August 2020

check for updates

\begin{abstract}
This study aimed at investigating the Lycium chinense Miller leaf extract mineral and phenolic compound profiles as well as antioxidant and antimicrobial potential. We determined the leaf extract mineral composition, identified its major mineral components, and quantified secondary metabolites. We also measured the leaf extract antioxidant potential and found that it varies in a concentration-dependent manner. We observed a significant and higher positive correlation between DPPH and ABTS assays compared with the total phenolic and flavonoid content. Furthermore, our assay results positively correlated with several observed acids, indicating their strong association with the L. chinense antioxidant potential. Our cytotoxic assay revealed weak toxicity at higher tested concentrations. Our MIC assay showed that the 80\% methanol extract effectively inhibited the growth of Escherichia coli Castellani and Chalmers (ATCC35150). The 625-ppm leaf extract completely suppressed the growth of Staphylococcus aureus Rosenbach (ATCC13150), Bacillus cereus (ATCC 14579), and Helicobacter pylori (ATCC43504). These results allow us to understand the indigenous medicinal value of L. chinense. Our study suggests that the $L$. chinense leaf extract phenolic compounds possess a good antioxidant activity against free radicals and are effective antimicrobial agents. Finally, the presence and high level of diverse minerals suggest the potential of L. chinense for nutraceutical and functional food applications.
\end{abstract}

Keywords: Lycium chinense; MTT assay; MIC assay; microorganisms; secondary metabolites; leaf extract

\section{Introduction}

Recently, several studies focused on plant phenolic compounds owing to their significant potential for promoting human health and lowering the hazards of various diseases [1-3]. Mineral elements and phenolic compounds are considered to play important roles in the antioxidant properties of plants $[4,5]$. Minerals such as $\mathrm{Zn}, \mathrm{Cu}$, and Re reportedly play important roles in the antioxidant potential of plants by serving as cofactors for antioxidant enzymes and cytochromes [6,7]. Other microelements such as K, $\mathrm{Na}, \mathrm{Mg}, \mathrm{Ca}, \mathrm{P}, \mathrm{S}, \mathrm{Co}$, and Se are important building blocks for several enzymes, including superoxide dismutase (SOD), peroxidase (POX), and catalase (CAT) that protect the cell membrane [6]. Mn is 
an antioxidant constituent that plays an important role in reactive oxygen species (ROS) scavenging in cells $[8,9]$. Further, certain trace elements such as $\mathrm{Cd}$ and $\mathrm{Pb}$ are toxic. $\mathrm{Pb}$ accumulation in plants is carcinogenic and causes neurological disorders, whereas $\mathrm{Al}$ accumulation in plants is associated with Alzheimer's disease [10]. Some of these elements, such as $\mathrm{Mn}, \mathrm{Cu}$, and $\mathrm{Fe}$, need to be present in balanced proportions, as they are toxic in nature at higher concentrations [11,12]. The daily intake of these elements is important to maintain an antioxidant enzyme balance [13]. However, to date, no evidence is available about the phenolic compound and mineral element composition of plants. Therefore, studying these profiles in plants is essential.

Free radicals are produced during metabolic processes and present serious health risks. ROS, such as $\mathrm{O}^{2-}, \mathrm{OH}^{-}$, and $\mathrm{NO}$, contribute to the degradation of cellular components such as DNA, proteins, and lipids, causing several diseases, including cardiovascular and inflammatory diseases, aging, carcinogenesis, and sclerosis [14]. Therefore, the application of synthetic chemical compounds with higher antioxidant potentials could be useful in treating such diseases [15]. However, such chemical compounds as an antioxidant might cause various human health problems [16].

Synthetic antimicrobial agents are used to prevent microorganism-induced food spoilage [17-19]. Moreover, pharmacological studies discovered several new antibiotics for the treatment of various diseases caused by infectious microorganisms. The widespread use of antibiotics is an important factor in the development of multidrug-resistant microbial strains $[3,20]$. Current research interests are focused on plant-based solutions to develop remedies for such infectious diseases and overcome the aforementioned drawbacks. Furthermore, secondary metabolites, such as phenolic compounds, present in medicinal plants have been proven effective against a wide range of pathogenic microbes, making them potential alternative antimicrobial agents [1,2].

Lycium chinense Miller, commonly known as boxthorn, belongs to the family Solanaceae and is a perennial plant; it is widely distributed in Korea, China, Japan, and several European countries [21]. In traditional medicine, this plant is widely used as a health food supplement [22], improving vision and wellness [23]. Extracts of this plant were shown to possess certain pharmacological properties including antidiabetic, antiaging [21,23], anti-inflammatory [24], hepatoprotective [25,26], and antioxidant properties [27-29]. Several studies have attributed these health benefits to various secondary metabolites, including flavonoids and phenolics [29], alkaloids, terpenoids, organic acids, and their derivatives [30]. Increased evidence of the safety and efficacy of the phytochemicals present in L. chinense extracts has been accumulated recently. However, limited information is available on its biological properties and secondary compound compositions. Therefore, in this study, we focused on determining the phenolic compound and mineral content of $L$. chinense extracts and investigating its potential antioxidant and antimicrobial effects. In addition, this study was also extended to elucidate the possible cytotoxic and irritation potential of L. chinense leaves. We hypothesized that the phenolic compounds present in the leaf extracts of L. chinense contribute to its antioxidant activity and the inhibition of microbial growth.

\section{Results and Discussion}

\subsection{Mineral Elements}

An imbalance in the intake of mineral elements could lead to various health problems [10]. Moreover, mineral elements play important roles in the antioxidant properties of plants [31]. Therefore, considering the importance of trace elements, it is important to analyze the plant mineral element concentration and composition profile. In the present study, we analyzed the mineral element content of the leaf extracts using the ICP-MS method and observed significant differences in the mineral element concentrations (Tables 1 and 2). 
Table 1. Calibration curves, limit of detection (LOD), and limit of quantitation (LOQ) of the 19 elements examined in this study.

\begin{tabular}{|c|c|c|c|c|c|c|c|}
\hline \multirow{2}{*}{$\begin{array}{c}\text { Element } \\
\mathrm{Al}\end{array}$} & \multirow{2}{*}{$\begin{array}{c}\begin{array}{c}\text { Concentration } \\
\mathbf{( m g ~ L}^{\mathbf{1}} \mathbf{)}\end{array} \\
0.5-10\end{array}$} & \multirow{2}{*}{$\begin{array}{c}\begin{array}{c}\text { Linearity } \\
\left(\mathbf{r}^{\mathbf{2}}\right)\end{array} \\
0.999932\end{array}$} & \multirow{2}{*}{$\begin{array}{c}\text { Slope (S) } \\
3730\end{array}$} & \multirow{2}{*}{$\begin{array}{c}\text { Response } \\
\text { SD } \\
358.88\end{array}$} & \multirow{2}{*}{$\begin{array}{c}\mathrm{RSD}^{\mathrm{c}} \\
\mathbf{( \% )}\end{array}$} & \multicolumn{2}{|c|}{$\begin{array}{c}\operatorname{LOD}^{b} \text { LOQ }^{b} \\
\mu \mathrm{g} \mathrm{mL}^{-1}\end{array}$} \\
\hline & & & & & & 0.288643 & 0.962145 \\
\hline As & $0.5-10$ & 0.999876 & 47.10 & 3.54 & 0.75 & 0.225478 & 0.751592 \\
\hline $\mathrm{Ba}$ & $0.5-10$ & 0.999825 & 5071 & 505.09 & 0.99 & 0.298811 & 0.996036 \\
\hline $\mathrm{Bi}$ & $0.5-10$ & 0.999907 & 286.5 & 38.39 & 1.34 & 0.401990 & 1.339965 \\
\hline $\mathrm{Ca}$ & $0.5-10$ & 0.999576 & 8157 & 1103.17 & 1.15 & 0.405726 & 1.352421 \\
\hline $\mathrm{Cd}$ & $0.5-10$ & 0.999812 & 2007 & 156.53 & 0.78 & 0.233976 & 0.779920 \\
\hline Co & $0.5-10$ & 0.999131 & 1197 & 111.51 & 0.93 & 0.279474 & 0.931579 \\
\hline $\mathrm{Cr}$ & $0.5-10$ & 0.999841 & 4921 & 522.49 & 1.06 & 0.318527 & 1.061756 \\
\hline $\mathrm{Cu}$ & $0.5-10$ & 0.999852 & 19,530 & 1778.00 & 0.91 & 0.273118 & 0.910394 \\
\hline $\mathrm{Fe}$ & $0.5-10$ & 0.999803 & 4031 & 352.03 & 0.87 & 0.261992 & 0.873307 \\
\hline $\mathrm{Li}$ & $0.5-10$ & 0.999783 & 32,120 & 3995.40 & 1.24 & 0.373169 & 1.243898 \\
\hline $\mathrm{Mg}$ & $0.5-10$ & 0.999738 & 19,920 & 2106.85 & 0.94 & 0.317297 & 1.057656 \\
\hline $\mathrm{Mn}$ & $0.5-10$ & 0.999901 & 31,120 & 3071.07 & 0.98 & 0.296054 & 0.986848 \\
\hline $\mathrm{Ni}$ & $0.5-10$ & 0.999757 & 1951 & 174.43 & 0.89 & 0.268216 & 0.894054 \\
\hline $\mathrm{Pb}$ & $0.5-10$ & 0.999792 & 277.0 & 37.92 & 1.37 & 0.410686 & 1.368953 \\
\hline Se & $0.5-10$ & 0.999913 & 72.12 & 8.72 & 1.21 & 0.362729 & 1.209096 \\
\hline $\mathrm{Ag}$ & $0.5-10$ & 0.999942 & 20,240 & 1753.28 & 0.86 & 0.259874 & 0.866245 \\
\hline $\mathrm{Ti}$ & $0.5-10$ & 0.999927 & 38,130 & 2907.65 & 0.76 & 0.228769 & 0.762562 \\
\hline $\mathrm{Zn}$ & $0.5-10$ & 0.999799 & 5112 & 378.98 & 0.74 & 0.222406 & 0.741354 \\
\hline
\end{tabular}

\footnotetext{
${ }^{\text {a }}$ The calibration curve was obtained using 3-7 different concentrations of a standard solution for each element.

$\mathrm{b}$ The LOD and LOQ were determined using each calibration curve as follows: $\mathrm{LOD}=3 \times \mathrm{SD} / \mathrm{S}$ and $\mathrm{LOQ}=10 \times$

$\mathrm{SD} / \mathrm{S}$, where $\mathrm{SD}$ is the standard deviation of the response and $\mathrm{S}$ is the slope of each calibration curve.
}

Table 2. Mineral content in the Lycium chinense leaf extracts.

\begin{tabular}{cc}
\hline Element & Concentration $\left(\mu \mathbf{g ~ m L}^{-\mathbf{1}}\right)$ \\
\hline $\mathrm{Al}$ & $0.389 \pm 0.0053$ \\
$\mathrm{As}$ & $0.046 \pm 0.0319$ \\
$\mathrm{Ba}$ & $0.048 \pm 0.0023$ \\
$\mathrm{Bi}$ & $0.062 \pm 0.0197$ \\
$\mathrm{Ca}$ & $69.17 \pm 0.5610$ \\
$\mathrm{Cd}$ & $0.088 \pm 0.0004$ \\
$\mathrm{Co}$ & $0.133 \pm 0.0025$ \\
$\mathrm{Cr}$ & $0.094 \pm 0.0012$ \\
$\mathrm{Cu}$ & $0.016 \pm 0.0017$ \\
$\mathrm{Fe}$ & $0.028 \pm 0.0028$ \\
$\mathrm{Li}$ & $0.038 \pm 0.0010$ \\
$\mathrm{Mg}$ & $15.40 \pm 0.1040$ \\
$\mathrm{Mn}$ & $0.345 \pm 0.0025$ \\
$\mathrm{Ni}$ & $0.110 \pm 0.0019$ \\
$\mathrm{~Pb}$ & $0.043 \pm 0.0015$ \\
$\mathrm{Se}$ & $0.161 \pm 0.0823$ \\
$\mathrm{Ag}$ & $0.052 \pm 0.0823$ \\
$\mathrm{Ti}$ & $0.050 \pm 0.0002$ \\
$\mathrm{Zn}$ & $0.041 \pm 0.0031$ \\
\hline
\end{tabular}

The seven most dominant minerals (in decreasing order) were as follows: $\mathrm{Ca}$ (92.77) $>\mathrm{Mg}$ (28.68) $>\mathrm{Mn}(1.696)>\mathrm{Fe}(0.875)>\mathrm{Al}(0.551)>\mathrm{Zn}(0.303)>\mathrm{Ba}(0.269)$. Among the minerals, $\mathrm{Cu}$ exhibited the lowest concentration $(0.031 \pm 0.001 \mathrm{mg} / \mathrm{mL})$. The presence of elements such as $\mathrm{As}, \mathrm{Cd}, \mathrm{Pb}, \mathrm{Hg}$, and $\mathrm{Al}$ beyond certain concentrations can be toxic [32]. Interestingly, in the present study, the concentrations of these elements were within the environmental safety limits. The concentrations of other elements such as $\mathrm{Zn}, \mathrm{Fe}$, and $\mathrm{Cu}$ were observed to be within the permissible levels. It is worth mentioning that the L. chinense leaf extracts could serve as good sources of minerals (for dietary intake) and play important roles in maintaining health. 


\subsection{Correlation between Antioxidant Properties and Minerals}

Several metal elements are known for their antioxidant properties. In the present study, a moderate and positive correlation was observed between the mineral elements and antioxidant activity, indicating that these elements contributed to the antioxidant properties of the plant (Table 3).

Table 3. Pearson's correlation coefficients of the antioxidant properties and minerals.

\begin{tabular}{|c|c|c|c|c|c|c|c|c|c|c|c|c|c|c|c|c|c|c|c|}
\hline Assays & $\mathrm{Al}$ & As & $\mathrm{Ba}$ & $\mathrm{Bi}$ & $\mathrm{Ca}$ & $\mathrm{Cd}$ & Co & $\mathrm{Cr}$ & $\mathrm{Cu}$ & $\mathrm{Fe}$ & $\mathrm{Li}$ & $\mathrm{Mg}$ & Mn & $\mathrm{Ni}$ & $\mathrm{Pb}$ & Se & $\mathrm{Ag}$ & Ti & $\mathrm{Zn}$ \\
\hline PPH & -0.72 & $\begin{array}{c}0.999 \\
*\end{array}$ & $\begin{array}{c}0.999 \\
*\end{array}$ & .989 & 0.995 & 993 & 927 & $\begin{array}{c}0.999 \\
*\end{array}$ & 0.989 & 989 & 0.989 & $\begin{array}{c}0.999 \\
*\end{array}$ & .989 & 989 & 989 & 0.994 & .241 & .995 & .865 \\
\hline $\mathrm{A}$ & & 0.997 & . & 4 & y & 6 & & 0.997 & 4 & 4 & 4 & 0.997 & 94 & 994 & 94 & $\begin{array}{c}0.998 \\
*\end{array}$ & 283 & 0.989 & .842 \\
\hline TPC & -0.700 & $\underset{* *}{0.972}$ & $\underset{* *}{0.981}$ & 0.983 & $\underset{*}{0.998}$ & 996 & 0.914 & $\underset{* *}{0.900}$ & 0.983 & 0.983 & 0.983 & $\begin{array}{c}0.990 \\
* *\end{array}$ & 0.983 & 0.983 & 0.983 & 0.990 & 0.208 & $\begin{array}{c}0.998 \\
*\end{array}$ & 0.882 \\
\hline TFC & -0.798 & 0.988 & 0.988 & $\begin{array}{c}0.999 \\
*\end{array}$ & 0.976 & 0.972 & 0.964 & 0.988 & $\begin{array}{c}0.999 \\
*\end{array}$ & $\begin{array}{c}0.999 \\
*\end{array}$ & $\begin{array}{c}0.999 \\
*\end{array}$ & 0.988 & $\begin{array}{c}0.999 \\
*\end{array}$ & $\begin{array}{c}0.999 \\
*\end{array}$ & $\begin{array}{c}0.999 \\
*\end{array}$ & $\underset{* *}{0.980}$ & 0.351 & 0.976 & 0.802 \\
\hline
\end{tabular}

${ }^{*}$ Correlation is significant at the 0.05 level (two-tailed). ${ }^{* *}$ Correlation is significant at the 0.01 level (two-tailed).

A positive and significantly high correlation $(r=0.997, p=0.05)$ was observed between Se and the antioxidant activity (ABTS radical scavenging activity). Conversely, a strong and positive correlation was recorded between $\mathrm{As}, \mathrm{Ba}, \mathrm{Ca}, \mathrm{Cr}, \mathrm{Mg}$, and Ti and the total phenolic content (TPC). Minerals such as $\mathrm{Bi}, \mathrm{Cu}, \mathrm{Fe}, \mathrm{Li}, \mathrm{Mn}, \mathrm{Ni}, \mathrm{Pb}$, and Se positively correlated with the total flavonoid content (TFC), indicating that these minerals might be a part of the phenolic compounds and play vital roles in the antioxidant (AO) properties of the leaf extracts. In the present study, a strong and positive correlation was observed between minerals such as $\mathrm{Bi}, \mathrm{Co}, \mathrm{Cu}, \mathrm{Fe}, \mathrm{Cr}$, and $\mathrm{Pb}$ and 1,1-diphenyl-2-picrylhydrazyl (DPPH) and 2,2'-azino-bis-3-ethylbenzthiazoline-6-sulphonic acid (ABTS). The present study also corroborated with the study of Perna et al. [33], describing a significant and positive correlation between the metal content and antioxidant activities. This study also corresponds to the study conducted by Solayman et al. [34], as we report a close and positive correlation between metal ions and the AO properties. Moreover, metals such as $\mathrm{Cu}, \mathrm{Zn}$, and $\mathrm{Mn}$ are essential co-factors for and integral parts of the superoxide dismutase enzyme required for the conversion of superoxide into hydrogen peroxide [35]. However, as per our study, other mineral elements such as $\mathrm{Al}, \mathrm{Ca}, \mathrm{Li}, \mathrm{Mg}$, $\mathrm{Se}, \mathrm{Ag}$, Ti, and $\mathrm{Zn}$ might not affect the antioxidant properties as non-significant correlations were observed between them.

\subsection{The TPC, TFC, and Phenolic Compound Composition of L. chinense Leaf Extracts}

The total phenolic and flavonoid content of the L. chinense leaf extracts, determined using a calibration curve $\left(R^{2}=0.988\right)$, was $7.55 \pm 0.22$ gallic acid equivalent $/ g$, and the total flavonoid content $\left(R^{2}=0.989\right)$ was $0.02 \pm 0.001$ quercetin equivalent/g (Table 4$)$. The determination of phenolic compounds using the Folin-Ciocalteu method tends to be inaccurate owing to the presence of non-phenolic compounds such as sugar and amino acids in the tested samples.

Table 4. Antioxidant activity, total phenolic content, and total flavonoid content of Lycium chinense.

\begin{tabular}{lccc}
\hline \multicolumn{1}{c}{ Assays } & Extracts & BHT & $\begin{array}{c}\text { Control } \\
\text { Ascorbic Acid }\end{array}$ \\
\hline DPPH * (IC50) $^{*} 70.99 \pm 7.95$ & $34.00 \pm 1.00$ & \\
ABTS * (IC50) & $1772.31 \pm 10.87$ & & $100.05 \pm 3.50$ \\
TPC (mgGAE/g) & $7.55 \pm 0.22$ & & \\
TFC (mgQE/g) & $0.02 \pm 0.001$ & & \\
\hline
\end{tabular}

\footnotetext{
* The inhibitory concentration $\left(\mathrm{IC}_{50}\right)$ value in $\mu \mathrm{g} / \mathrm{mL}$ indicates the amount of test sample needed to inhibit or scavenge $50 \%$ of the radicals present in the reaction mixture.
}

The phenolic compounds vary widely in their structure (owing to the presence of a hydroxyl group in their chemical structure) and are responsible for various biological activities [36]. LC-MS/MS is widely used for the identification and quantification of several phenolic compounds [37]. This study 
identified and quantified phenolic compounds in the L. chinense leaf extracts using LC-MS/MS (Figures 1 and 2).

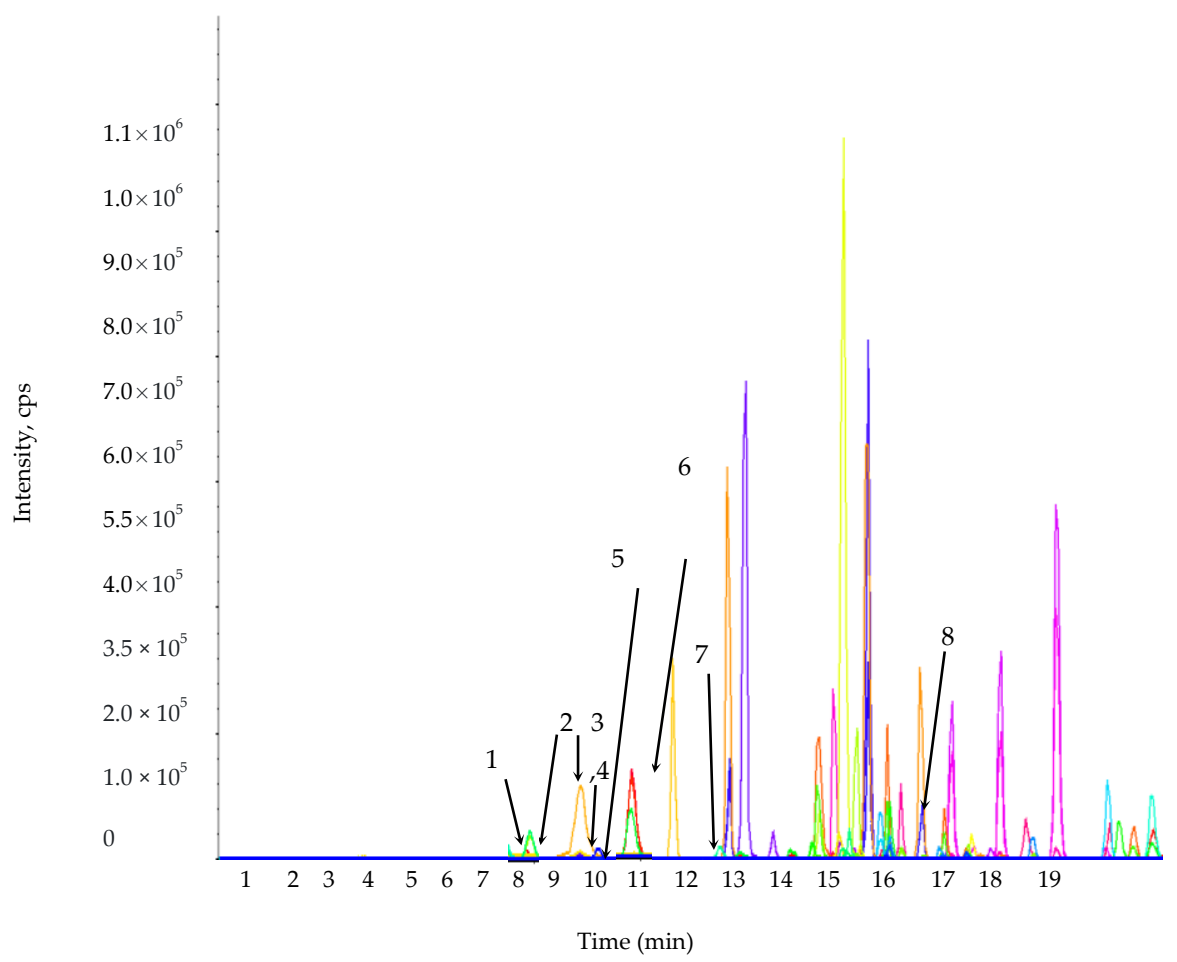

Figure 1. Multiple reaction monitoring mode (MRM) ion chromatogram of the selected phenolic compound standards. 1. Protocatechuic acid; 2. Chlorogenic acid; 3. Rutin; 4. p-Hydroxybenzoic acid; 5. Caffeic acid; 6. Gentisic acid; 7. $p$-Coumaric acid; 8. Salicylic acid.

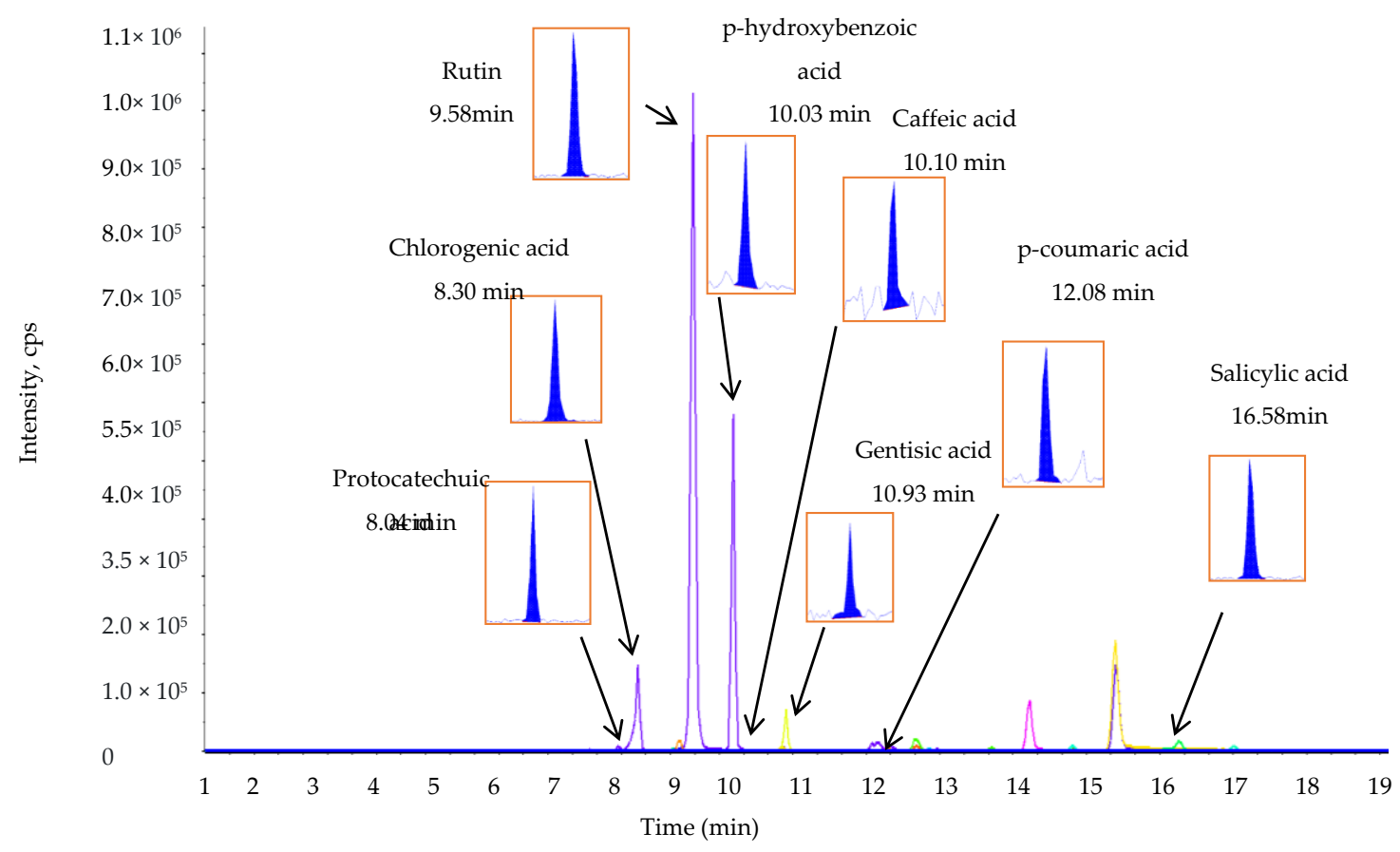

Figure 2. Representative MRM ion chromatogram of the phenolic compounds from the L. chinense leaf extracts. The extract ion chromatograms of the individual phenolic metabolites with small peaks are given in the rectangular boxes with their retention time. 
The concentrations of the phenolic compounds present in the sample were determined on the basis of the peak area. Among the quantified compounds, protocatechuic acid $\left(1198.70 \pm 5.00 \mu \mathrm{g} \mathrm{g}^{-1}\right)$, hydroxybenzoic acid $\left(529.70 \pm 6.15 \mu \mathrm{g} \mathrm{g}^{-1}\right)$, and $p$-coumaric acid $(466.90 \pm 6.50)$ were the most predominant phenolic compounds, accounting for more than $60 \%$ of the total phenolic compound concentration, whereas caffeic acid was the least abundant phenolic acid $\left(67.60 \pm 3.00 \mu \mathrm{g} \mathrm{g}^{-1}\right)$ as shown in Table 5.

Table 5. LC-MS/MS parameters of the phenolic compound quantitative analyses.

\begin{tabular}{|c|c|c|c|c|c|c|c|c|c|}
\hline Phenolic Compounds & $\begin{array}{l}\text { Retention } \\
\text { Time }\end{array}$ & $\underset{(m / z)^{\mathrm{a}}}{\mathrm{Q} 1}$ & $\underset{(m / z)}{\mathrm{Q} 3}$ & $\underset{\mathrm{c}}{\mathrm{DP}(\mathrm{V})}$ & $\underset{d}{E P(V)}$ & $\underset{\mathrm{e}}{\mathrm{CEP}(\mathrm{V})}$ & $\underset{f}{C E}(e V)$ & $\underset{\mathrm{g}}{\mathrm{CXP}(\mathrm{V})}$ & $\begin{array}{c}\text { Phenolic } \\
\text { Compounds } \\
\text { ( } \mu \mathrm{g} / \mathrm{g} \text { Dry Weight } \\
\text { of Leaf Extract) }\end{array}$ \\
\hline Chlorogenic acid & 8.30 & 352.846 & 191.000 & -21.000 & -7.000 & -32.000 & -30.000 & -10.000 & $192.30 \pm 4.50$ \\
\hline Rutin & 9.58 & 609.002 & 299.700 & -91.000 & -10.500 & -34.000 & -52.000 & -14.000 & $119.70 \pm 2.50$ \\
\hline$p$-Hydroxybenzoic acid & 10.02 & 136.885 & 92.900 & -16.000 & -8.500 & -12.000 & -24.000 & -6.000 & $529.70 \pm 6.15$ \\
\hline$p$-Coumaric acid & 12.08 & 162.866 & 118.900 & -11.000 & -7.000 & -14.000 & -20.000 & -6.000 & $466.90 \pm 6.50$ \\
\hline Salicylic acid & 16.58 & 136.874 & 92.900 & -16.000 & -7.500 & -12.000 & -22.000 & -6.000 & $134.30 \pm 3.00$ \\
\hline
\end{tabular}

\subsection{Antioxidant Activity}

The antioxidant potential of the L. chinense leaf extract was determined using the DPPH and ABTS assays (Table 4). The results showed that the leaf extract has a greater ability to scavenge the DPPH and ABTS radicals with IC50 values of $70.99 \pm 7.95$ and $1772.31 \pm 10.87$, respectively. Although the antioxidant potential data obtained between the antioxidant assays were somewhat different, they highly correlated between themselves. This difference could be due to the variation in the response of the antioxidant substances to different radicals present in each assay. Meanwhile, higher positive correlations were observed between the TPC, TFC, and antioxidant properties (Table 6).

Table 6. Pearson's correlation coefficients of the antioxidant properties and phenolic acids.

\begin{tabular}{ccccccccccccc}
\hline & ABTS & DPPH & TPC & TFC & $\begin{array}{c}\text { Protocate- } \\
\text { Chuic } \\
\text { Acid }\end{array}$ & $\begin{array}{c}\text { Chlorogenic } \\
\text { Acid }\end{array}$ & Rutin & $\begin{array}{c}p \text {-Hydroxy- } \\
\text { Benzoic } \\
\text { Acid }\end{array}$ & $\begin{array}{c}\text { Caffeic } \\
\text { Acid }\end{array}$ & $\begin{array}{c}\text { Gentisic } \\
\text { Acid }\end{array}$ & $\begin{array}{c}p \text {-Coumaric } \\
\text { Acid }\end{array}$ \\
\hline ABTS & 1 & $\begin{array}{c}0.999 \\
*\end{array}$ & $\begin{array}{c}0.997 \\
\text { Acid }\end{array}$ & $\begin{array}{c}0.997 \\
*\end{array}$ & $0.997 *$ & 0.949 & 0.990 & $0.999 *$ & 0.997 & $0.999 *$ & $0.999 *$ & 0.969 \\
DPPH & $\begin{array}{c}0.999 \\
*\end{array}$ & 1 & $\begin{array}{c}0.999 \\
*\end{array}$ & 0.993 & 0.993 & 0.934 & 0.991 & 0.997 & $\begin{array}{c}0.999 \\
*\end{array}$ & $0.997 *$ & $0.998 *$ & 0.957 \\
\hline
\end{tabular}

** Correlation is significant at the 0.01 level (two-tailed). ${ }^{*}$ Correlation is significant at the 0.05 level (two-tailed).

Several studies have attributed the antioxidant potential of plants species to their phytochemical components, including phenolic compounds, which effectively act as reducing agents, hydrogen donors, and singlet oxygen quenchers [38,39]. In the present study, the Pearson's correlation coefficients between the phenolic compounds and antioxidant potentials (1/RC50) varied greatly. The DPPH assay exhibited higher positive correlation with the gentisic acid $\left(\mathrm{r}^{2}=0.900, p<0.05\right), p$-coumaric acid $\left(\mathrm{r}^{2}=1, p<0.01\right)$, and caffeic acid $\left(\mathrm{r}^{2}=0.999, p<0.05\right)$, whereas the ABTS radical scavenging activities positively correlated with the $p$-coumaric acid $\left(\mathrm{r}^{2}=0.999, p<0.05\right)$, hydroxybenzoic acid $\left(\mathrm{r}^{2}=0.999\right.$, $p<0.05)$, gentisic acid $\left(r^{2}=0.999, p<0.05\right)$, and protocatechuic acid $\left(r^{2}=0.997, p<0.05\right)$, indicating that these compounds might be strongly associated with the antioxidant potential of L. chinense. Other studies deducted positive associations between the plant phenolic compounds and antioxidant activities [38,40,41], which were also in a good agreement with the present study, indicating the higher contribution of these compounds to the antioxidant properties of the leaf extracts. It has been reported that phenolic compounds, such as phenolic acid and flavonoids, act as antioxidants by chelating metal cations, scavenging radicals, or donating hydrogen ions or electrons [42,43]. It has also been 
reported that the antioxidant properties of individual phenolic compounds depend on the number of hydroxyl $(\mathrm{OH})$ groups and their arrangement in the aromatic rings as well as the availability of electron-donating ions [44-46]. Other studies reported the existence of synergistic or additive effects between the individual phenolic compounds that contribute to plant antioxidant activities [47]. Thus, the results of the present study indicate that the phenolic compounds of the leaf extracts and their synergistic effects are important contributors to the antioxidant properties of L. chinense.

\subsection{Cytotoxic Effect}

The MTT assay has been widely used as a method to assess cell viability through the production of water soluble products with increased sensitivity and higher flexibility in the operation as well as cost and time efficiency [48]. To quantitatively estimate living cells, the amount of formazan crystals produced during metabolic processes in active NIH $3 \mathrm{~T} 3$ cell lines is determined [49]. L. chinense leaf extracts reportedly exhibit higher cytotoxic effects in cancer cells [50]. However, the cytotoxic potential of the concentrated leaf extract of $L$. chinense on normal cells and its half maximal inhibitory concentration (IC50) has not yet been determined. Therefore, in this study, we documented the cytotoxicity of various L. chinense leaf extract concentrations in the NIH-3T3 cell line (Table 7). As shown in Figures 3 and 4, the L. chinense leaf extracts exhibited cytotoxicity in a concentration-dependent manner $(50 \mathrm{mg} / \mathrm{mL})$.

Table 7. Pearson correlation coefficients between the phenolic compounds and cytotoxicity of the leaf extracts.

\begin{tabular}{lc}
\hline \multicolumn{1}{c}{ Phenolic Compounds } & Cytotoxicity \\
\hline Protocatechuic acid & $0.957^{* *}$ \\
Chlorogenic acid & $0.998^{*}$ \\
Rutin & 0.870 \\
p-Hydroxybenzoic acid & 0.872 \\
Caffeic acid & 0.919 \\
Gentisic acid & 0.819 \\
p-Coumaric acid & $0.984^{*}$ \\
Salicylic acid & $0.998^{*}$ \\
\hline
\end{tabular}

** Correlation is significant at the 0.01 level (two-tailed). ${ }^{*}$ Correlation is significant at the 0.05 level (two-tailed).

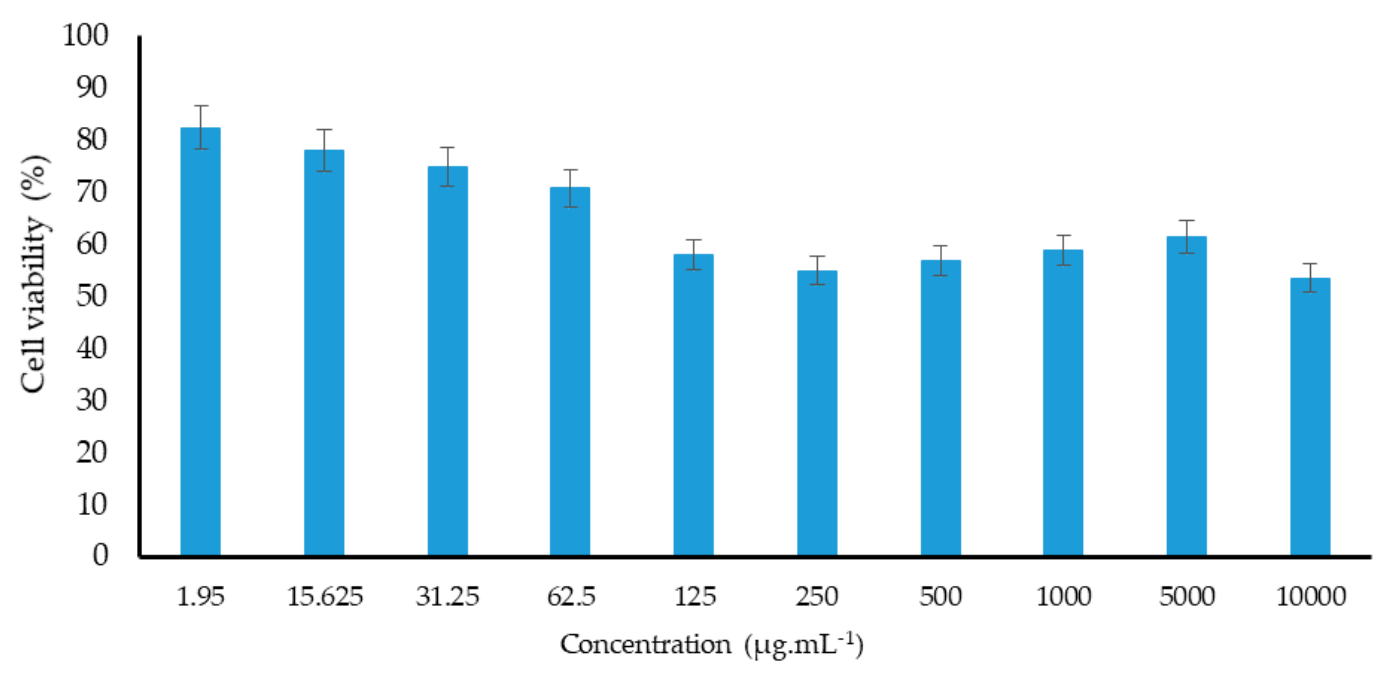

Figure 3. The effect of leaves extracts concentration on cell viability on NIH 3T3 cells lines. 

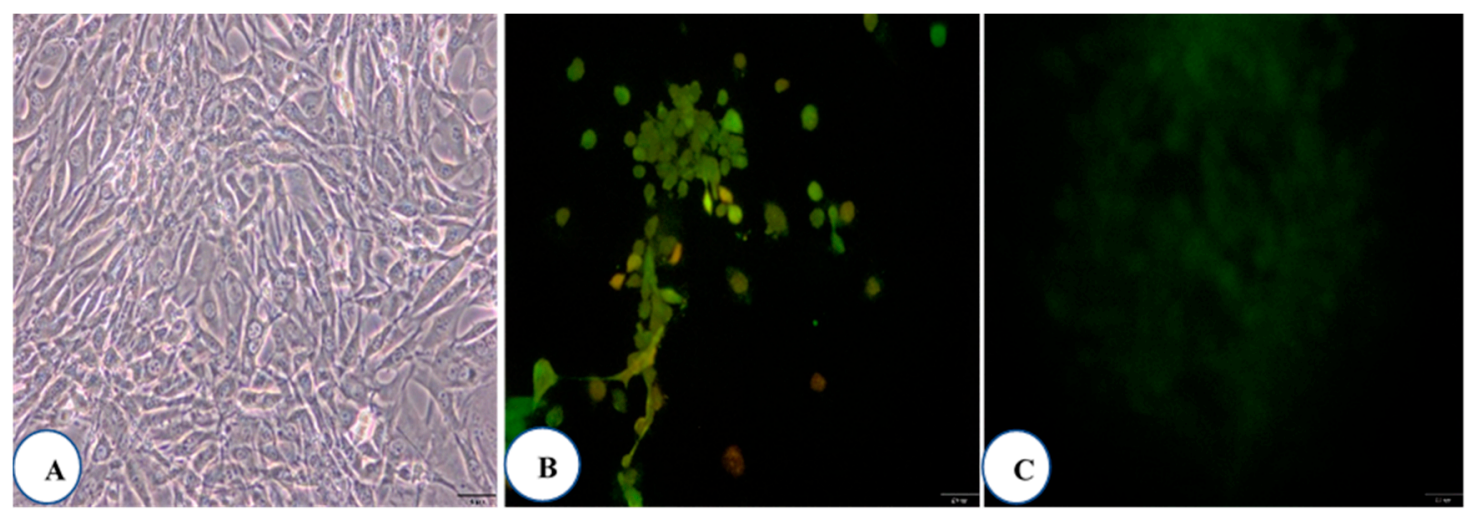

Figure 4. Cytotoxic effect of the leaf extracts ( $\mathrm{IC}_{50}$ concentrations) on the NIH $3 \mathrm{~T} 3$ cell lines. (A) Bright field, (B) AO/EB staining, (C) ROS.

The results showed that higher leaf extract concentrations reduced the NIH-3T3 cell number. The cell viability was not significantly affected when the concentration of the extracts was between 1.95 and $62.5 \mathrm{ppm}$. However, the cell viability significantly reduced (nearly by 53\%) when the leaf extract concentration increased to $10,000 \mathrm{ppm}$. However, it has been observed that higher than the required amounts of bioactive compounds might cause an imbalance in their function, which might not help prevent cellular oxidative stress and thus lead to cell death [51].

Several studies indicated that phenolic compounds are the main phytochemicals responsible for the antioxidant and antimicrobial properties of plant extracts [52-54]. These phytochemicals are also responsible for inducing cytotoxicity. In the present study, the phenolic compound profile of the L. chinense leaf extracts was investigated, which exhibited high concentrations of polyphenols, such as protocatechuic acid, hydroxybenzoic acid, $p$-coumaric acid, genitisic acid, salicylic acid, caffeic acid, and rutin, which could be responsible for the cytotoxic properties. Moreover, previous studies indicated that phenolic compounds have implications in strong cytotoxicity. For instance, higher rutin, quercetin, chlorogenic acid, and luteolin concentrations effectively inhibited the growth of NIH-3T3 cells [55-57], whereas quercetin derivatives, such as chloronaphthoquinone quercetin, prevented the proliferation of NIH 3T3 cells [58]. Moreover, we described, in this study, a strong positive correlation between cytotoxicity and protocatechuic acid $(\mathrm{r}=0.957, p<0.01)$, chlorogenic acid $(\mathrm{r}=0.998, p<0.05)$, $p$-coumaric acid ( $\mathrm{r}=0.984, p<0.05)$, or salicylic acid $(\mathrm{r}=0.998, p<0.05)$, as presented in Table 7 , indicating that the higher concentrations of these compounds might be associated with L. chinense cytotoxicity. However, further studies are still necessary to identify the phenolic compounds responsible for this effector mechanism.

\subsection{Irritation Potential of Leaf Extracts Measured by the HET-CAM Assay}

The hen's egg test on the chorioallantoic membrane (HET-CAM) is considered a rapid and cost effective approach to examine the irritation potential of leaf extracts used in the cosmetic industry and in the development of cosmeceuticals [59]. Different concentrations of leaf extracts and $0.1 \mathrm{M}$ $\mathrm{NaOH}$ (positive control) are used to assess the irritation potential of the leaf extracts using different parameters (hemorrhage, coagulation, and lysis), and changes were observed as shown in Figure 5.

We could conclude, from the results of this experiment, that lower extract concentrations did not exhibit embryonic toxicity (Table 8). In the present study, higher extract concentrations showed a certain level of irritation compared to the lower concentrations. The results indicated that lower concentrations of antioxidant compounds present in the leaf extracts are safer for topical application and beneficial for product preparation. 

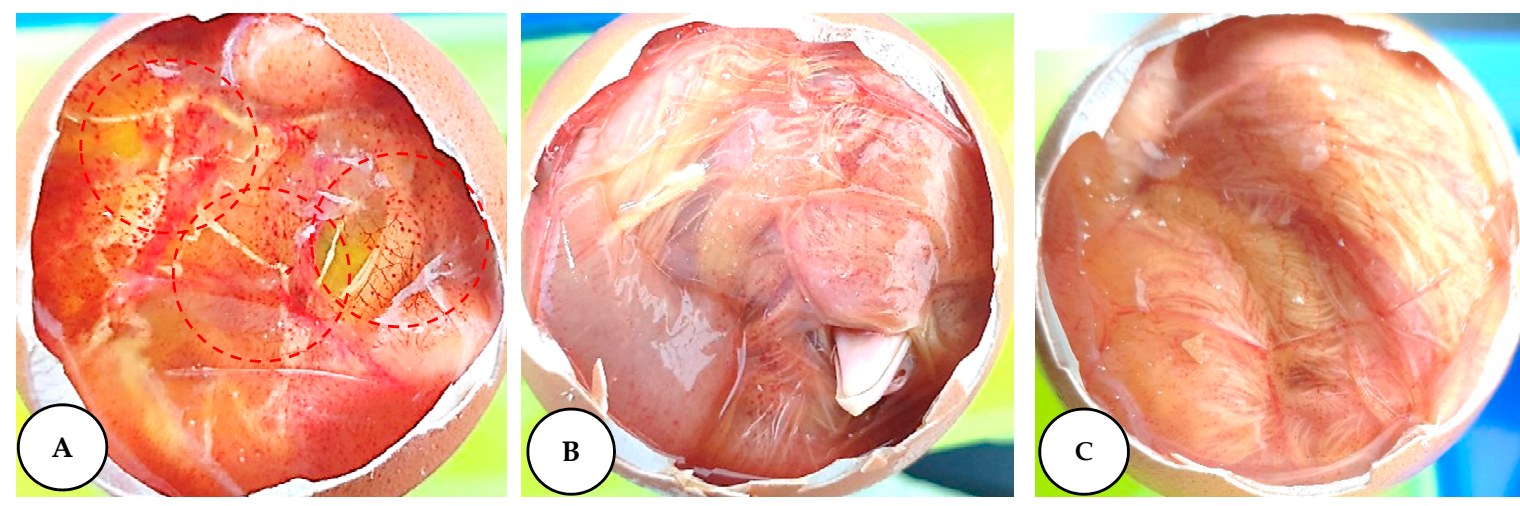

Figure 5. The hen's egg test on the chorioallantoic membrane (HET-CAM) assay. (A) $\mathrm{NaOH}(0.1 \mathrm{M})$ positive control; (B) negative control (distilled water); (C) test sample.

Table 8. Assessment of test sample irritation potential in the HET-CAM assay.

\begin{tabular}{lcc}
\hline \multicolumn{1}{c}{ Samples } & Irritation Score & Irritation Assessment \\
\hline Negative control & 0 & Non-irritant \\
NaOH $(0.1 \mathrm{M})$ & 18.82 & Strong irritant \\
Leaf extracts $(50 \mathrm{mg} / \mathrm{mL})$ & 0 & Non-irritant \\
\hline
\end{tabular}

\subsection{Antimicrobial Activity}

\subsubsection{Minimum Inhibitory Concentration (MIC)}

The antimicrobial activity of the L. chinense leaf extracts was tested against several pathogenic Gram-positive and Gram-negative bacterial strains, assessed by determining the inhibition zone and MIC (Table 9). The MIC assay showed that the $80 \%$ methanol extracts of $L$. chinense effectively inhibited the growth of the E. coli strains (MIC $=125 \mu \mathrm{g} \mathrm{mL}{ }^{-1}$ ). The leaf extracts completely suppressed the growth of $S$. aureus and $H$. pylori at a concentration of $625 \mathrm{ppm}$. However, none of the tested microorganisms were susceptible to the leaf extracts. For instance, the K. pneumonia and S. typhimurium strains were less sensitive to the plant extracts, as indicated by their higher MIC values $(>1000)$.

Table 9. Evaluation of the leaf extract minimum inhibitory concentration (MIC) against selected pathogens.

\begin{tabular}{lc}
\hline \multicolumn{1}{c}{ Bacterial Strains } & MIC $(\mathbf{p p m})-$ \\
\hline B. cereus & 625 \\
K. pneumoniae & $>1000$ \\
S. aureus & 625 \\
S. typhimurium & $>1000$ \\
B. subtilis & $>1000$ \\
E. coli & 155 \\
H. pylori & 625 \\
\hline
\end{tabular}

\subsubsection{Disc Diffusion Test}

The zone of inhibition of the leaf extracts at a concentration of $1000 \mu \mathrm{g} / \mathrm{mL}$ exhibited a significant difference in the case of all selected bacterial strains (Table 10). 
Table 10. Antimicrobial activity of the leaf extracts based on the zone of inhibition against selected pathogens.

\begin{tabular}{lcc}
\hline \multicolumn{1}{c}{ Bacterial Strains } & Leaf Extracts & Tetracycline (10 $\mathbf{~ m g})$ \\
\cline { 2 - 3 } & \multicolumn{2}{c}{ Zone of Inhibition $(\mathrm{cm})-$} \\
\hline B. cereus & 1.4 & 1.6 \\
K. pneumoniae & 0.5 & 0.8 \\
S. aureus & 0.9 & 2.0 \\
S. typhimurium & 0.9 & 1.1 \\
B. subtilis & 1.2 & 1.2 \\
E. coli & 1.8 & 1.9 \\
H. pylori & 1.7 & 1.8 \\
\hline
\end{tabular}

Among the tested microbes, E. coli was more susceptible; it was effectively inhibited by the leaf extract (zone of inhibition $=1.8 \mathrm{~cm}$ ). Further, $K$. pneumoniae was the least susceptible (zone of inhibition $=0.5 \mathrm{~cm}$ ). The extracts showed low to intermediate inhibitory effects on S. aureus and S. typhimurium, with an inhibition zone of $0.9 \mathrm{~cm}$ (Figure 6).
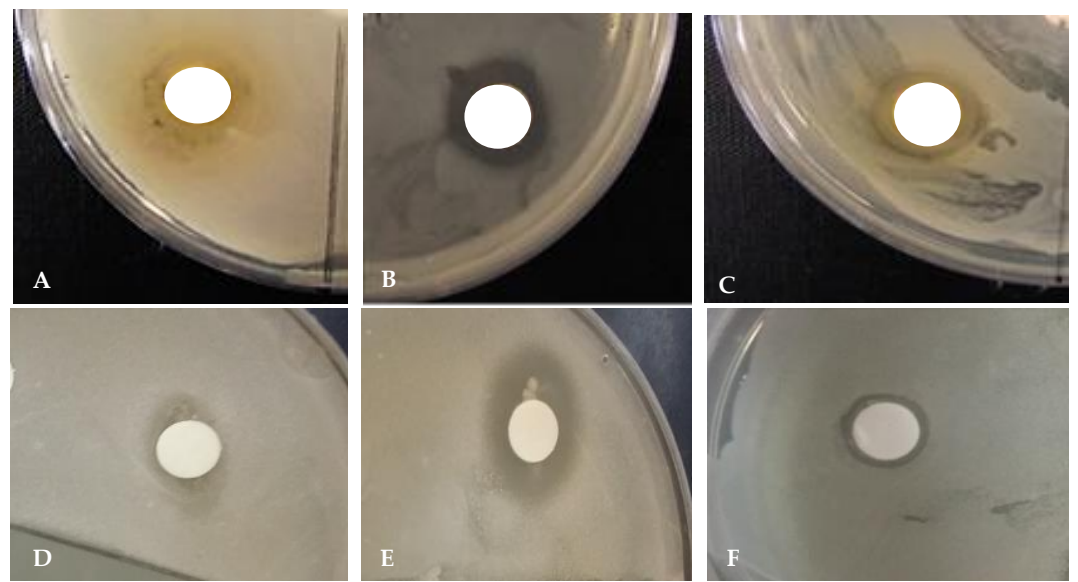

Figure 6. The zone of inhibition of the L. chinense methanol extract, (A) E. coli; (B) B. cereus; (C) H. pylori; (D) B. subtilis; (E) S. aureus; (F) S. typhimurium.

The antimicrobial activity of the L. chinense leaf extract might be due to the phytochemicals present in these plants, which are rich in phenolic acids, such as protocatechuic, gentisic, $p$-hydroxybenzoic, chlorogenic, $p$-coumaric, salicylic, and caffeic acid, as well as flavonoids (rutin). Several previous studies observed reductions in microbial populations upon treatment with the phenolic compounds of plant extracts [60-63]. For instance, $p$-hydrobenzoic acid effectively inhibited the growth of Staphylococcus aureus [64]. In another study, chlorogenic acid was found to be the most effective against E. coli, S. aureus, and B. subtilis [65]. These compounds induced an increase in the outer- and plasma-membrane permeability of pathogenic microorganisms, leading to their death [65]. Therefore, it is likely that the higher phenolic compound concentrations of the L. chinense leaf extract could be associated with its antimicrobial activity.

\section{Materials and Methods}

\subsection{Chemicals}

All chemicals used in the present study were of analytical grade. Compounds such as the Folin-Ciocalteu reagent, quercetin, kanamycin, vancomycin, $\alpha$-tocopherol, tert-butyl-4-hydroxy toluene (BHT), 2,2-diphenyl-1-picryl-hydrazyl-hydrate (DPPH), 2,2'-azino-bis-3-ethylbenzthiazoline-6-sulphonic acid, 2,4,6-tri(2-pyridyl)-s-triazine (TPTZ), 
and gallic acid were obtained from Sigma-Aldrich Chemical Co. (St. Louis, MO, USA). Hydrogen peroxide $\left(\mathrm{H}_{2} \mathrm{O}_{2}\right)$ was obtained from Sigma-Aldrich (Seoul, Korea), and nitric acid $\left(\mathrm{HNO}_{3}\right)$ was purchased from Showa Chemical Industry Co. Ltd. (Tokyo, Japan). Ultrapure distilled water, which was used in the analysis, was purchased from the Zeneer power 1 system (Human Corporation, Seoul, Korea). The 19 multielement standards used in the analysis (micro- and macro-elements) were purchased from Perkin Elmer (Seoul, Korea). The multielement stock solutions were obtained from Quality Control Standard 26, (Inorganic Ventures, Christiansburg, VA, USA). All analytical equipment required for sample preparation and mineral quantification were cleaned with $\mathrm{HNO}_{3}(2 \%, v / v)$ and rinsed thrice with ultrapure water.

\subsection{Sample Digestion}

Leaves extracts of $L$. chinense were pre-digested in $\mathrm{HNO}_{3}$ as previously described (US Environmental Protection Agency, 2007). Briefly, $0.5 \mathrm{~g}$ of the sample was mixed with $7 \mathrm{~mL}$ of $70 \% \mathrm{HNO}_{3}$ at room temperature for $6 \mathrm{~h}$. After incubation, $1 \mathrm{~mL}$ of $\mathrm{H}_{2} \mathrm{O}_{2}$ was added to the mixture. The mixture was microwave digested by increasing the temperature to $180^{\circ} \mathrm{C}$ for $15 \mathrm{~min}$. The digestion was complete when the sample turned colorless. The final volume of the digested sample was adjusted to $50 \mathrm{~mL}$ by adding ultrapure distilled water. Blank samples were prepared via the same method.

\subsection{Instrumentation and Quantification of Minerals}

Inductively coupled plasma atomic emission spectroscopy (ICP-AES) (Optima 7300 DV, Perkin Elmer, Korea) was used to quantify the concentrations of the 19 mineral elements in the leaf extracts of L. chinense. The operational conditions and optics used for the determination of the concentrations of the different mineral elements were as follows: $15 \mathrm{~L} \mathrm{~min}^{-1}$ axial mode plasma, $0.2 \mathrm{~L} \mathrm{~min}^{-1}$ auxilliary; $0.65 \mathrm{~L} \mathrm{~min}^{-1}$ nebulizer; $1300 \mathrm{~W}$ RF powder; and $1.5 \mathrm{~mL} \mathrm{~min}^{-1}$ flow rate. Except for $\mathrm{K}$ and $\mathrm{Na}$, the radial mode of the ICP-AES was used to quantify the mineral elements. In contrast, the axial mode was used for $\mathrm{K}$ and $\mathrm{Na}$. Approximately 3-7-point calibration curves were used for quantitation, and the concentration ranges for the 19 elemental STDs are shown in Table 1.

The limit of quantitation (LOQ) and limit of detection (LOD) for the 19 elements were calculated using the following calibration curve:

$$
\mathrm{LOD}=3 \times \mathrm{SD} / \mathrm{S}, \mathrm{LOQ}=10 \times \mathrm{SD} / \mathrm{S},
$$

where SD is the standard deviation of a response and $\mathrm{S}$ is the slope of the calibration curve.

\subsection{Preparation of Plant Extracts}

L. chinense seedlings were grown in an experimental field of Kangwon National University, South Korea ( $37^{\circ} 52^{\prime} 09.53^{\prime \prime} \mathrm{N} ; 127^{\circ} 44^{\prime} 42.82^{\prime \prime} \mathrm{E}$; at an altitude of $\left.100 \mathrm{~m}\right)$. The leaves of 2-year-old L. chinense were collected in early November 2019. The harvested leaf sample was immediately washed with distilled water. Then, the collected leaf samples were sliced and freeze-dried for $24 \mathrm{~h}$. Approximately $2 \mathrm{~g}$ of the freeze-dried fine powder sample was mixed with $20 \mathrm{~mL}$ of $80 \%$ methanol at room temperature $\left(25^{\circ} \mathrm{C}\right.$ ). Then, the mixture was filtered through a filter paper (Whatman No. 1, Maidstone, UK) to remove the debris. The solvents were evaporated at $40{ }^{\circ} \mathrm{C}$ in a rotary evaporator (Eyela, SB-1300, Shanghai Eyela Co. Ltd., China). The residual extracts were dissolved in $80 \%$ methanol $(300 \mathrm{~mL})$ and stored at $4{ }^{\circ} \mathrm{C}$ until further use.

\subsection{Determination of Total Phenolic Content}

The total phenolic content was determined according to the method described by Singleton and Rossi [66]. Initially, in a 10-mL test tube, $100 \mu \mathrm{L}$ of leaf extract $\left(1 \mathrm{mg} \mathrm{mL}^{-1}\right)$ and $50 \mu \mathrm{L}$ of Folin-Ciocalteu $(1 \mathrm{M})$ were mixed with $1.85 \mathrm{~mL}$ of distilled water and incubated at room temperature for $5 \mathrm{~min}$. Then, after $5 \mathrm{~min}, 400 \mu \mathrm{L}$ of sodium carbonate $\left(\mathrm{Na}_{2} \mathrm{CO}_{3}\right)$ was mixed into the solution, followed by the 
addition of distilled water to obtain a final volume of $4 \mathrm{~mL}$. Deionized distilled water served as a blank. The reaction solution was maintained at room temperature for $1 \mathrm{~h}$ in the dark. The absorbance value of the reaction mixture was measured using a spectrophotometer (Jasco V530 UV-VIS spectrophotometer, Tokyo, Japan) at $725 \mathrm{~nm}$ against the blank. The TPC was expressed in terms of the gallic acid equivalent (GAE) per $g$ of the dry sample.

\subsection{Estimation of Total Flavonoid Content}

The total flavonoid content (TFC) was determined following the method described by Moreno et al. [67]. In a $10-\mathrm{mL}$ test tube, $500 \mu \mathrm{L}$ of leaf extract $\left(1 \mathrm{mg} \mathrm{mL}^{-1}\right)$ was added to $100 \mu \mathrm{L}$ of $10 \%$ aluminum nitrate and $100 \mu \mathrm{L}$ of potassium acetate $\left(\mathrm{KCH}_{3} \mathrm{COO}\right)(1 \mathrm{M})$. To the reaction mixture, $4.3 \mathrm{~mL}$ of $80 \%$ ethanol was added to achieve a final volume of $5 \mathrm{~mL}$. After mixing thoroughly, the reaction mixture was incubated at room temperature for $50 \mathrm{~min}$. The absorbance of the mixture was recorded against the blank using a spectrophotometer (Jasco V530 UV-VIS spectrophotometer, Tokyo, Japan) at $415 \mathrm{~nm}$. The total flavonoid content was expressed in terms of the quercetin equivalent (QE) per $g$ of the dry sample.

\subsection{Estimation of Phenolic Compounds by Liquid Chromatography-Mass Spectrometry/Mass Spectrometry (LC-MS/MS)}

The phenolic compound concentration and composition were identified in L. chinense using a liquid chromatography-mass spectrometry/mass spectrometry (LC-MS/MS) system, as described previously by Chung et al. [68]. Pumps (Agilent 1200, Agilent Technologies, Palo Alto, CA, USA) and an autosampler (Agilent 1100 series, Agilent Technologies, Palo Alto, CA, USA) coupled to an API 2000 series, mass spectrometer (Applied Biosystems, Ontario, Canada) were integrated to the LC system. The chromatographic separation of phenolic compounds was performed using a C18 column $(4.6 \times 250 \mathrm{~mm}, 5 \mu \mathrm{m})$. A negative ion mode was used. The following parameters were used to determine the phenolic compounds present in the samples: Nebulizer gas pressure, drying gas pressure, collision gas pressure, and curtain gas pressure, set at 40, 70, 2, and 20 psi, respectively. The drying gas temperature and capillary voltage were set to $350{ }^{\circ} \mathrm{C}$ and $4.5 \mathrm{kV}$, respectively. The mobile phase comprised $0.1 \%$ formic acid $(\mathrm{HCOOH})(v / v)$ in water (mobile phase $\mathrm{A}$ ) and $0.1 \%$ acetonitrile $(\mathrm{C} 2 \mathrm{H} 3 \mathrm{~N})$ in water $(95: 5, v / v)$ (mobile phase B). The following mobile phase gradient elution program was used for the efficient separation of compounds: 10-40\% B for 0-10 $\mathrm{min} ; 40-50 \%$ B for 10-20 $\mathrm{min} ; 50-100 \%$ B for $20-25 \mathrm{~min}$; $100-10 \%$ B for 25-26 min; and 10\% B for 26-30 min. During the experiment, the column temperature was maintained at $25^{\circ} \mathrm{C}$. The volume of the injected sample was $10 \mu \mathrm{L}$. The mobile phase was eluted at a constant flow rate of $0.7 \mathrm{~mL} \mathrm{~min}^{-1}$. Electrospray ion source (ESI) was used as the source for recording the mass-spectrometry data; the process was performed in the negative mode under the multiple reaction monitoring (MRM) mode. Different mass spectrometric parameters, such as entrance potential (EP), collision energy (CE), declustering potential (DP), cell entrance potential (CEP), and collision cell exit potential (CXP), were determined for each MRM transition monitored. The analysis of allelochemicals for each sample were performed in triplicate.

\subsection{Antioxidant Activity}

\subsubsection{Evaluation of the 1,1-Diphenyl-2-Picrylhydrazyl (DPPH) Radical Scavenging Assay}

The free radical scavenging potential of the leaf extract of $A J$ was measured in vitro using the DPPH assay following the method described earlier by Xing et al. [69]. Briefly, $200 \mu \mathrm{L}$ of sample extract (0.05-10 $\left.\mathrm{mg} \mathrm{mL}^{-1}\right)$ was added to $4.5 \mathrm{~mL}$ of DPPH $(0.004 \%$ in methanol). The reaction mixture was mixed thoroughly and maintained at $25^{\circ} \mathrm{C}$ for $40 \mathrm{~min}$. Then, the absorbance of the reaction mixture was measured using a spectrophotometer (Jasco V530 UV-VIS spectrophotometer, Tokyo, Japan) at 
$517 \mathrm{~nm}$. A-tocopherol was used as the reference standard antioxidant. The free radical scavenging activity was estimated by the following equation:

$$
\mathrm{DPPH} \text { scavenging activity }=\left(\mathrm{Abs}_{\mathrm{control}}-\mathrm{Abs}_{\text {sample }}\right) / \mathrm{Abs}_{\mathrm{control}}
$$

where $\mathrm{Abs}_{\text {control }}$ is the absorbance of the reaction mixture without the leaf extract. $\mathrm{Abs}_{\text {sample }}$ is the absorbance of the reaction mixture with the leaf extract. The IC50 value was determined from the plotted graph. Calculated inhibitory concentration $\left(\mathrm{IC}_{50}\right)$ values indicate the amount of test sample needed to inhibit or scavenge $50 \%$ of the radicals present in the reaction mixture.

\subsubsection{Evaluation of the 2,2' -Azino-bis-3-Ethylbenzthiazoline-6-Sulphonic Acid (ABTS) Assay}

The 2,2' -azino-bis-3-ethylbenzthiazoline-6-sulphonic acid (ABTS), also known as the ABTS cation scavenging assay was carried out following the method described previously [70]. Briefly, the ABTS solution was prepared by reacting $7.4 \mathrm{mM}$ ABTS and $2.6 \mathrm{mM}$ potassium persulphate in an equal ratio $(1: 1, v / v)$. Then, the reaction mixture was maintained at room temperature for $12 \mathrm{~h}$. The reaction mixture was then diluted with $80 \%$ methanol, and the absorbance of the reaction mixture solution was observed at $734 \mathrm{~nm}$ using a spectrophotometer (Jasco V530 UV-VIS spectrophotometer, Tokyo, Japan). For the spectrophotometric measurement of the samples, $1 \mathrm{~mL}$ of diluted ABTS and $100 \mathrm{~mL}$ of the sample were mixed. Trolox at various concentrations (500-1000 $\mu \mathrm{M})$ was used to make the standard curve. The ability to scavenge ABTS radicals of the sample was calculated by the following equation:

$$
\text { ABTS scavenging activity }=\left(\mathrm{Abs}_{\text {control }}-\mathrm{Abs}_{\text {sample }}\right) / \mathrm{Abs}_{\mathrm{control}} \times 100
$$

where $\mathrm{Abs}_{\text {control }}$ is the absorbance value of the ABTS solution without the test sample. Abs sample is the absorbance value of the ABTS solution with the test sample.

\subsection{Cytotoxicity}

The cell line NIH/3T3 ATCC ${ }^{\circledR}$ CRL-1658 ${ }^{\mathrm{TM}}$ (Embryonic fibroblast) was provided by the School of Biomedical Science, Kangwon National University, South Korea. Each cell line was cultured in a suitable medium to obtain the desired growth, and the growth curve of the cell line was plotted. The cytotoxicity of the leaf extracts was evaluated by treating the NIH/3T3 cell line with the 3-(4,5-dimethyl thiazol-2-yl)-2,5-diphenyl tetrazolium bromide solution (MTT assay) according to a method described elsewhere [71]. The NIH/3T3 cells (at a density of $6 \times 10^{3}$ per well $100 \mathrm{~mL}$ of the medium) were grown in a 96-well microtitration plate. After $24 \mathrm{~h}$ of incubation, the cells were treated with different concentrations (the maximum concentration was $50 \mu \mathrm{g} \cdot \mathrm{mL}^{-1}$ ) of the leaf extracts for $72 \mathrm{~h}$. The MTT solution $\left(5 \mathrm{mg} \cdot \mathrm{mL}^{-1}\right.$ of final concentration) was added to each well and incubated at $37^{\circ} \mathrm{C}$ for $4 \mathrm{~h}$. Then, the supernatant was removed, and the resultant formazan crystals were dissolved in dimethyl sulfoxide (DMSO) (Sigma, MO, USA). The amount of produced formazan was directly proportional to the number of living cells. The absorbance was measured using a microplate reader (Thermofisher Scientific Instrument Co. Ltd., Shanghai, China) at 570 nm. The MTT assay for the cytotoxicity of commercially available identified compounds was performed similarly as described above for leaf extracts. Tamoxifen (Sigma, MO, USA) was used as the positive control in the present study.

$$
\% \text { cell viability }=\text { A570 of treated cells/A570 of control cells } \times 100
$$

\subsection{Assessment of Irritation Potential of L. chinense Leaf Extracts in a Fertile Chicken Egg}

The antiallergic properties of leaf extracts was determined by the HET-CAM test (Hen's egg chorioallantoic membrane test). Fresh and fertilized eggs where purchased from a chicken farm. The fertilized eggs were incubated at $37^{\circ} \mathrm{C}$ with a relative humidity of $60 \%$. The eggs were rotated manually each day by $180^{\circ}$ to ensure the proper development of the embryo. On the ninth day, 
the incubated eggshell was scratched around the air sack and opened up. Carefully, the cell membranes were removed to expose the CAM. The leaf extracts (dissolved in DMSO) at a volume of $0.2 \mathrm{~mL}$ were treated to the CAM. The irritant effect of leaf extracts on blood vessels, capillaries, and albumin was examined and scored (between 0 and 21) for each egg on the basis of hemorrhage, coagulation, and lysis for $300 \mathrm{~s}$. The ocular irritation index (OII) was then obtained by the following equation:

$$
\mathrm{OH}=(301-\mathrm{h}) \times 5 / 300+(301-1) \times 7 / 300+(301-\mathrm{c}) \times 9 / 300
$$

where $\mathrm{h}$ is the time to beginning of hemorrhage, 1 time to lysis, and $\mathrm{c}$ time to coagulation. The following classification was used: $\mathrm{OII} \leq 0.9$, slightly irritating; $0.9<\mathrm{OII} \leq 4.9$, moderately irritating; $4.9<\mathrm{OII} \leq 8.9$, irritating; and $8.9<\mathrm{OII} \leq 21$, severely irritating.

\subsection{In Vitro Assay for Antimicrobial Activity}

\subsubsection{Disc diffusion Method}

Selected pathogenic bacterial strains were acquired from the Department of Food Science and Biotechnology, Kangwon National University, South Korea. Leaf extracts were tested against Bacillus cereus (ATCC 14579), Klebsiella pneumonia subsp. pneumoniae (Schroeter) Trevisan ATCC 9621, Staphylococcus aureus Rosenbach (ATCC13150), Salmonella enteritidis typhimurium Kauffmann and Edwards (ATCC14028), Bacillus subtilis (KCCM 11316), Escherichia coli Castellani and Chalmers (ATCC35150), and Helicobacter pylori (ATCC43504). The antimicrobial activity of the leaf extract of L. chinense was evaluated by performing the agar disc diffusion method described elsewhere [72]. Initially, bacterial strains were spread on the solid MRS agar medium at room temperature. Leaf extracts (50 $\mu \mathrm{L}$ each) at a concentration of $1 \mathrm{mg} / \mathrm{mL}$ of the dried plant sample were used to soak filter paper discs ( $6 \mathrm{~mm}$, Whatman, no. 3). The soaked filter paper discs were maintained at room temperature for 10 min to evaporate the methanol and subsequently placed on the MRS medium containing the tested microbial strains. Kanamycin or tetracycline was used as the positive control. Then, the culture plates were incubated at $37^{\circ} \mathrm{C}$ for $18-24 \mathrm{~h}$.

\subsubsection{Minimum Inhibitory Concentration (MIC)}

The minimum inhibitory concentration (MIC) required to inhibit the growth of microorganisms was carried out according to the method described by Kobayashi et al. [73]. The leaf extract was dissolved in $80 \%$ methanol to obtain a concentration of $10 \mathrm{mg} \mathrm{mL}^{-1}$. Then, $20 \mu \mathrm{L}$ of the $10 \mathrm{mg} \mathrm{mL}^{-1}$ plant extract solution and $180 \mu \mathrm{L}$ of standard-grown bacterial culture were dispensed to the first well of 96-well assay microplates (SPL, Life Science Co. Ltd., Pocheon, South Korea). The leaves extracts were further diluted by a two-fold dilution series to give a final concentration of $7.8 \mu \mathrm{g} \mathrm{mL}{ }^{-1}$, and the final volume in each well was $200 \mu \mathrm{L}$. The tested bacterial strains were incubated at $37^{\circ} \mathrm{C}$ for $24 \mathrm{~h}$. The amount of plant sample (lowest concentration) that produce no visible growth of bacteria in the first $24 \mathrm{~h}$ of incubation compared with the control was considered the MIC. Tetracycline was used as the positive control.

\subsection{Statistical Analysis}

Statistical analysis was recorded as the mean \pm standard deviation using the analysis of variance (ANOVA). Significant differences between the parameters were determined by Duncan's multiple comparison test at $p<0.05$ and $p<0.01$. The interrelationship between minerals and phenolic compounds with antioxidant and cytotoxic properties were assessed by Pearson's correlation coefficient using SPSS version 20 (SPSS, 2011). All experiments were performed in triplicate.

Author Contributions: M.T. and B.K.G. contributed by doing the experiment and writing of the manuscript; C.Y.Y. supervised the experiment; D.-H.O. and R.C. contributed by doing the experiment on cytotoxicity effects; I.M.C., 
S.-H.K., C.K., and Y.-J.K. contributed by analyzing phenolic compounds and editing the revised manuscript. All authors have read and agreed to the published version of the manuscript.

Funding: This work was supported by a BrainKorea21 plus (BK21+, grant no. 22A20153813519, team: Omics Research of Crop Bioresources for Future, Konkuk University), the National Research Foundation of Korea, Republic of Korea.

Acknowledgments: This work was supported by funding from the KU research professor program.

Conflicts of Interest: The authors declare no conflict of interest.

\section{References}

1. Negi, P.; Jayaprakasha, G.; Jena, B. Antioxidant and antimutagenic activities of pomegranate peel extracts. Food Chem. 2003, 80, 393-397. [CrossRef]

2. Zahin, M.; Aqil, F.; Ahmad, I. Broad spectrum antimutagenic activity of antioxidant active fraction of Punica granatum L. peel extracts. Mutat. Res. Toxicol. Environ. Mutagen. 2010, 703, 99-107. [CrossRef] [PubMed]

3. Edward-Jones, V.; Rai, M.K.; Kon, K.V. Alternative antimicrobial approaches to fighting multidrug-resistant infections. In Fighting Multidrug Resistance with Herbal Extracts, Essential Oils and Their Components; Academic Press: Amsterdam, The Netherlands, 2013; Volume 1, pp. 1-8.

4. Aras, A.; Dogru, M.; Bursal, E. Determination of antioxidant potential of Nepeta nuda subsp. lydiae. Anal. Chem. Lett. 2016, 6, 758-765. [CrossRef]

5. Olalere, O.A.; Abdurahman, N.H.; Yunus, R.B.M.; Alara, O.R.; Ahmad, M.M.; Abayomi, O.O.; Nour, A.H.; Ruth, A.O. Mineral element determination and phenolic compounds profiling of oleoresin extracts using an accurate mass LC-MS-QTOF and ICP-MS. J. King Saud. Univ. Sci. 2019, 31, 859-863. [CrossRef]

6. Sofo, A.; Lundegårdh, B.; Mårtensson, A.; Manfra, M.; Pepe, G.; Sommella, E.; De Nisco, M.; Tenore, G.C.; Campiglia, P.; Scopa, A. Different agronomic and fertilization systems affect polyphenolic profile, antioxidant capacity and mineral composition of lettuce. Sci. Hortic. 2016, 204, 106-115. [CrossRef]

7. Liu, X.; Ardo, S.; Bunning, M.; Parry, J.; Zhou, K.; Stushnoff, C.; Stoniker, F.; Yu, L.; Kendall, P. Total phenolic content and DPPH radical scavenging activity of lettuce (Lactuca sativa L.) grown in Colorado. LWT 2007, 40, 552-557. [CrossRef]

8. Szymczycha-Madeja, A.; Welna, M.; Pohl, P. Elemental analysis of teas and their infusions by spectrometric methods. TrAC Trends Anal. Chem. 2012, 35, 165-181. [CrossRef]

9. Yanai, N.; Shiotani, S.; Hagiwara, S.; Nabetani, H.; Nakajima, M. Antioxidant Combination Inhibits Reactive Oxygen Species Mediated Damage. Biosci. Biotechnol. Biochem. 2008, 72, 3100-3106. [CrossRef]

10. Yokel, R.A.; Florence, R.L. Aluminum bioavailability from tea infusion. Food Chem. Toxicol. 2008, 46, 3659-3663. [CrossRef]

11. Michalak, A. Phenolic compounds and their antioxidant activity in plants growing under heavy metal stress. Pol. J. Environ. Stud. 2006, 15, 523-530.

12. Abu-Darwish, M.S.; Abu-Dieyeh, Z.H.; Mufeed, B.; Al-Tawaha, A.R.M.; Al-Dalain, S.Y.A. Trace element contents and essential oil yields from wild thyme plant (Thymus serpyllum L.) grown at different natural variable environments, Jordan. J. Food Agric. Environ. 2009, 7, 920-924.

13. Nuapia, Y.; Chimuka, L.; Cukrowska, E. Assessment of heavy metals in raw food samples from open markets in two African cities. Chemosphere 2018, 196, 339-346. [CrossRef]

14. Kozarski, M.; Klaus, A.S.; Jakovljevic, D.; Todorovic, N.; Vunduk, J.; Petrovic, P.; Niksic, M.; Vrvić, M.; Van Griensven, L.J. Antioxidants of edible mushrooms. Molecules 2015, 20, 19489-19525. [CrossRef] [PubMed]

15. Velioglu, Y.S.; Mazza, G.; Gao, L.; Oomah, B.D. Antioxidant activity and total phenolics in selected fruits, vegetables, and grain products. J. Agric. Food Chem. 1998, 46, 4113-4117. [CrossRef]

16. Safer, A.M.; Al-Nughamish, A.J. Hepatotoxicity induced by the anti-oxidant food additive, butylated hydroxytoluene (BHT), in rats: An electron microscopical study. Histol. Histopathol. 1999, 14, 391-406. [PubMed]

17. Schuenzel, K.M.; Harrison, M.A. Microbial antagonists of foodborne pathogens on fresh, minimally processed vegetables. J. Food Prot. 2002, 65, 1909-1915. [CrossRef] [PubMed]

18. Sokmen, A.; Gulluce, M.; Akpulat, H.A.; Daferera, D.; Tepe, B.; Polissiou, M.; Sokmen, M.; Şahin, F. The in vitro antimicrobial and antioxidant activities of the essential oils and methanol extracts of endemic Thymus spathulifolius. Food Control. 2004, 15, 627-634. [CrossRef] 
19. Tepe, B.; Daferera, D.; Sökmen, M.; Polissiou, A.M.; Sökmen, A. In Vitro antimicrobial and antioxidant activities of the essential oils and various extracts of Thymus eigiiM. Zohary et P.H. Davis. J. Agric. Food Chem. 2004, 52, 1132-1137. [CrossRef]

20. Paphitou, N.I. Antimicrobial resistance: Action to combat the rising microbial challenges. Int. J. Antimicrob. Agents 2013, 42, S25-S28. [CrossRef]

21. Myers, L.P.; Fan, R.; Zheng, Q.; Pruett, S.B. Sodium methyldithiocarbamate causes thymic atrophy by an indirect mechanism of corticosterone up-regulation. J. Immunotoxicol. 2005, 2, 97-106. [CrossRef]

22. Kim, J.-S.; Chung, H.Y. GC-MS analysis of the volatile components in dried boxthorn (Lycium chinensis) Fruit. J. Korean Soc. Appl. Boil. Chem. 2009, 52, 516-524. [CrossRef]

23. Potterat, O. Goji (Lycium barbarum and L. chinense): Phytochemistry, pharmacology and safety in the perspective of traditional uses and recent popularity. Planta Medica 2009, 76, 7-19. [CrossRef] [PubMed]

24. Lin, C.; Chuang, S.; Lin, J.; Yang, J. Evaluation of the antiinflammatory hepatoprotective and antioxidant activities of Lycium chinense from Taiwan. Phytomedicine 1997, 4, 213-220. [CrossRef]

25. Chin, Y.W.; Lim, S.W.; Kim, S.H.; Shin, D.Y.; Suh, Y.G.; Kim, Y.B.; Kim, Y.C.; Kim, J. Hepatoprotective pyrrole derivatives of Lycium chinense fruits. Bioorg. Med. Chem. Lett. 2003, 13, 79-81. [CrossRef]

26. Kim, S.Y.; Choi, Y.-H.; Huh, H.; Kim, J.; Kim, Y.C.; Lee, H.S. New antihepatotoxic cerebroside from Lyciumchinense fruits. J. Nat. Prod. 1997, 60, 274-276. [CrossRef] [PubMed]

27. Ionica, M.E.; Nour, V.; Trandafir, I. Polyphenols content and antioxidant capacity of goji fruits (Lycium chinense) as affected by the extraction solvents. South West. J. Hortic. Biol. Environ. 2012, 3, 121-129.

28. Kim, J.S. Comparison of antioxidant properties of water and ethanol extracts obtained from dried boxthorn (Lycium chinensis) fruit. Food Nutr. Sci. 2012, 3, 1307-1320.

29. Liu, S.-C.; Lin, J.-T.; Hu, C.-C.; Shen, B.-Y.; Chen, T.-Y.; Chang, Y.-L.; Shih, C.-H.; Yang, D.-J. Phenolic compositions and antioxidant attributes of leaves and stems from three inbred varieties of Lycium chinense Miller harvested at various times. Food Chem. 2017, 215, 284-291. [CrossRef]

30. Zhang, J.-X.; Guan, S.-H.; Feng, R.-H.; Wang, Y.; Wu, Z.-Y.; Zhang, Y.-B.; Chen, X.-H.; Bi, K.-S.; Guo, D.-A. Neolignanamides, lignanamides, and other phenolic compounds from the root bark of Lycium chinense. J. Nat. Prod. 2013, 76, 51-58. [CrossRef]

31. Liu, C.L.; Chen, Y.S.; Yang, J.H.; Chiang, B.H.; Hsu, C.K. Trace element water iproves the antioxidant activity of Buckwheat (Fagopyrum esculentum Moench) sprouts. J. Agric. Food Chem. 2007, 55, 8934-8940. [CrossRef]

32. Da Silva, A.L.O.; Barrocas, P.R.G.; Jacob, S.D.C.; Moreira, J.C. Dietary intake and health effects of selected toxic elements. Braz. J. Plant Physiol. 2005, 17, 79-93. [CrossRef]

33. Perna, A.M.; Simonetti, A.; Intaglietta, I.; Sofo, A.; Gambacorta, E. Metal content of southern Italy honey of different botanical origins and its correlation with polyphenol content and antioxidant activity. Int. J. Food Sci. Technol. 2012, 47, 1909-1917. [CrossRef]

34. Solayman, M.; Islam, A.; Paul, S.; Ali, Y.; Khalil, I.; Alam, N.; Gan, S.H. Physicochemical properties, minerals, trace elements, and heavy metals in honey of different origins: A comprehensive review. Compr. Rev. Food Sci. Food Saf. 2015, 15, 219-233. [CrossRef]

35. Fukai, T.; Ushio-Fukai, M. Superoxide dismutases: Role in redox signaling, vascular function, and diseases. Antioxid. Redox Signal. 2011, 15, 1583-1606. [CrossRef] [PubMed]

36. Bursal, E. Kinetic properties of peroxidase enzyme from chard (Beta vulgaris Subspeciescicla) leaves. Int. J. Food Prop. 2013, 16, 1293-1303. [CrossRef]

37. Bingol, M.N.; Bursal, E. LC-MS/MS analysis of phenolic compounds and in vitro antioxidant potential of stachys lavandulifolia vahl. var. brachydon boiss. Int. Lett. Nat. Sci. 2018, 72, 28-36. [CrossRef]

38. Nishimura, F.D.C.Y.; De Almeida, A.C.; Ratti, B.A.; Ueda-Nakamura, T.; Nakamura, C.V.; Ximenes, V.F.; Silva, S.D.O. Antioxidant effects of quercetin and naringenin are associated with impaired neutrophil microbicidal activity. Evid. Based Complement. Altern. Med. 2013, 2013, 1-7. [CrossRef]

39. Parhiz, H.; Roohbakhsh, A.; Soltani, F.; Rezaee, R.; Iranshahi, M. Antioxidant and anti-inflammatory properties of the citrus flavonoids hesperidin and hesperetin: An updated review of their molecular mechanisms and experimental models. Phytother. Res. 2014, 29, 323-331. [CrossRef]

40. Kamalakkannan, N.; Prince, P.S.M. Antihyperglycaemic and antioxidant effect of rutin, a polyphenolic flavonoid, in streptozotocin-induced diabetic wistar rats. Basic Clin. Pharmacol. Toxicol. 2006, 98, 97-103. [CrossRef] 
41. Kikuzaki, H.; Hisamoto, M.; Hirose, K.; Akiyama, K.; Taniguchi, H. Antioxidant properties of ferulic acid and its related compounds. J. Agric. Food Chem. 2002, 50, 2161-2168. [CrossRef]

42. Amarowicz, R.; Pegg, R.; Rahimi-Moghaddam, P.; Barl, B.; Weil, J. Free-radical scavenging capacity and antioxidant activity of selected plant species from the canadian prairies. Food Chem. 2004, 84, 551-562. [CrossRef]

43. Balasundram, N.; Sundram, K.; Samman, S. Phenolic compounds in plants and agri-industrial by-products: Antioxidant activity, occurrence, and potential uses. Food Chem. 2006, 99, 191-203. [CrossRef]

44. Zhang, H.-Y.; Sun, Y.-M.; Wang, X.-L. Substituent effects on $\mathrm{O}-\mathrm{H}$ bond dissociation enthalpies and ionization potentials of catechols: A DFT study and its implications in the rational design of phenolic antioxidants and elucidation of structure-activity relationships for flavonoid antioxidants. Chem. Eur. J. 2003, 9, 502-508. [CrossRef] [PubMed]

45. Moghaddam, M.; Mehdizadeh, L. Variability of total phenolic, flavonoid and rosmarinic acid content among Iranian basil accessions. LWT 2015, 63, 535-540. [CrossRef]

46. Neuhouser, M.L. Flavonoids and cancer prevention: What is the evidence in humans? Pharm. Biol. 2004, 42, 36-45. [CrossRef]

47. Mokrani, A.; Madani, K. Effect of solvent, time and temperature on the extraction of phenolic compounds and antioxidant capacity of peach (Prunus persica L.) fruit. Sep. Purif. Technol. 2016, 162, 68-76. [CrossRef]

48. Li, F.; Li, S.; Li, H.-B.; Deng, G.-F.; Ling, W.-H.; Xu, X.-R. Antiproliferative activities of tea and herbal infusions. Food Funct. 2013, 4, 530. [CrossRef]

49. Fontes, S.T.; Fernández, M.R.; Ogliari, F.A.; De Carvalho, R.V.; Moraes, R.R.; Pinto, M.B.; Piva, E. Tetrahydrofuran as solvent in dental adhesives: Cytotoxicity and dentin bond stability. Clin. Oral Investig. 2012, 17, 237-242. [CrossRef]

50. Georgiev, K.D.; Slavov, I.J.; Iliev, I. Synergistic growth inhibitory effects of Lycium barbarum (Goji berry) extract with doxorubicin against human breast cancer cells. J. Pharm. Pharmacol. Res. 2019, 3, 51-58. [CrossRef]

51. Rahal, A.; Kumar, A.; Singh, V.; Yadav, B.; Tiwari, R.; Chakraborty, S.; Dhama, K. Oxidative stress, prooxidants and antioxidants: The interplay. BioMed Res. Int. 2014, 2014, 1-19. [CrossRef]

52. Estevinho, L.M.; Pereira, A.; Moreira, L.F.; Dias, L.G.; Pereira, E.L. Antioxidant and antimicrobial effects of phenolic compounds extracts of Northeast Portugal honey. Food Chem. Toxicol. 2008, 46, 3774-3779. [CrossRef] [PubMed]

53. Aleksic, V.; Knezevic, P. Antimicrobial and antioxidative activity of extracts and essential oils of Myrtus communis L. Microbiol. Res. 2014, 169, 240-254. [CrossRef] [PubMed]

54. Llorent-Martínez, E.J.; Ortega-Barrales, P.; Panneerselvam, C.; Mocan, A.; Simirgiotis, M.; Ceylan, R.; Uysal, S.; Aktumsek, A. Evaluation of antioxidant potential, enzyme inhibition activity and phenolic profile of Lathyrus cicera and Lathyrus digitatus: Potential sources of bioactive compounds for the food industry. Food Chem. Toxicol. 2017, 107, 609-619. [CrossRef] [PubMed]

55. Araújo, K.C.F.; Costa, E.M.D.M.; Pazini, F.; Valadares, M.C.; De Oliveira, V. Bioconversion of quercetin and rutin and the cytotoxicity activities of the transformed products. Food Chem. Toxicol. 2013, 51, 93-96. [CrossRef] [PubMed]

56. Bonechi, C.; Donati, A.; Leone, G.; Consumi, M.; Lamponi, S.; Tamasi, G.; Rossi, C.; Magnani, A. Protective effect of quercetin and rutin encapsulated liposomes on induced oxidative stress. Biophys. Chem. 2018, 233, 55-63. [CrossRef]

57. Tamasi, G.; Baratto, M.C.; Bonechi, C.; Byelyakova, A.; Pardini, A.; Donati, A.; Leone, G.; Consumi, M.; Lamponi, S.; Magnani, A.; et al. Chemical characterization and antioxidant properties of products and by-products from Olea europaea L. Food Sci. Nutr. 2019, 7, 2907-2920. [CrossRef]

58. Danihelova, M.; Veverka, M.; Šturdík, E.; Jantova, S. Antioxidant action and cytotoxicity on HeLa and NIH-3T3 cells of new quercetin derivatives. Interdiscip. Toxicol. 2013, 6, 209-216. [CrossRef]

59. Lokman, N.A.; Elder, A.S.F.; Ricciardelli, C.; Oehler, M.K. Chick chorioallantoic membrane (CAM) assay as an in vivo model to study the effect of newly identified molecules on ovarian cancer invasion and metastasis. Int. J. Mol. Sci. 2012, 13, 9959-9970. [CrossRef]

60. Zheng, W.; Wang, S.Y. Antioxidant activity and phenolic compounds in selected herbs. J. Agric. Food Chem. 2001, 49, 5165-5170. [CrossRef] 
61. Saavedra, M.J.; Borges, A.; Dias, C.; Aires, A.; Bennett, R.N.; Rosa, E.; Simões, M. Antimicrobial activity of phenolics and glucosinolate hydrolysis products and their synergy with streptomycin against pathogenic bacteria. Med. Chem. 2010, 6, 174-183. [CrossRef]

62. Hirai, I.; Okuno, M.; Katsuma, R.; Arita, N.; Tachibana, M.; Yamamoto, Y. Characterisation of anti-Staphylococcus aureus activity of quercetin. Int. J. Food Sci. Technol. 2010, 45, 1250-1254. [CrossRef]

63. Cueva, C.; Moreno-Arribas, M.V.; Martin-Álvarez, P.J.; Bills, G.F.; Vicente, M.F.; Basilio, A.; Rivas, C.L.; Requena, T.; Rodríguez, J.M.; Bartolomé, B. Antimicrobial activity of phenolic acids against commensal, probiotic and pathogenic bacteria. Res. Microbiol. 2010, 161, 372-382. [CrossRef] [PubMed]

64. Liang, Y.; Xu, Q.; Xie, H.; Zhou, Y.; Wei, X. Chemical constituents from mango seed kernels and their antimicrobial activity. J. Trop. Subtrop. Bot. 2010, 18, 445-448.

65. Lou, Z.; Wang, H.; Zhu, S.; Ma, C.; Wang, Z. Antibacterial activity and mechanism of action of chlorogenic acid. J. Food Sci. 2011, 76, 398. [CrossRef] [PubMed]

66. Singleton, V.L.; Rossi, J.A., Jr. Colorimetry of total phenolics with phosphomolybdic-phosphotungstic acid reagents. Am. J. Enol. Vitic. 1965, 16, 144-158.

67. Moreno, M.I.; Isla, M.I.; Sampietro, A.R.; Vattuone, M.A. Comparison of the free radical-scavenging activity of propolis from several regions of Argentina. J. Ethnopharmacol. 2000, 71, 109-114. [CrossRef]

68. Chung, I.-M.; Chelliah, R.; Oh, D.-H.; Kim, S.-H.; Yu, C.Y.; Ghimire, B.K. Tupistra nutans wall. root extract, rich in phenolics, inhibits microbial growth and $\alpha$-glucosidase activity, while demonstrating strong antioxidant potential. Braz. J. Bot. 2019, 42, 383-397. [CrossRef]

69. Xiong, Q.; Kadota, S.; Tani, T.; Namba, T. Antioxidative effects of phenylethanoids from cistanche deserticola. Boil. Pharm. Bull. 1996, 19, 1580-1585. [CrossRef]

70. Thaipong, K.; Boonprakob, U.; Crosby, K.; Cisneros-Zevallos, L.; Byrne, D.H. Comparison of ABTS, DPPH, FRAP, and ORAC assays for estimating antioxidant activity from guava fruit extracts. J. Food Compos. Anal. 2006, 19, 669-675. [CrossRef]

71. Sandra, F.; Sudiono, J.; Trisfilha, P.; Pratiwi, D. Cytotoxicity of Alpinia galanga rhizome crude extract on NIH-3T3 cells. Indones. Biomed. J. 2017, 9, 23. [CrossRef]

72. Rios, J.; Recio, M. Medicinal plants and antimicrobial activity. J. Ethnopharmacol. 2005, 100, 80-84. [CrossRef] [PubMed]

73. Kobayashi, M.; Kakizono, T.; Nagai, S. Enhanced carotenoid biosynthesis by oxidative stress in acetate-induced cyst cells of a green unicellular alga, Haematococcus pluvialis. Appl. Environ. Microbiol. 1993, 59, 867-873. [CrossRef] [PubMed]

(C) 2020 by the authors. Licensee MDPI, Basel, Switzerland. This article is an open access article distributed under the terms and conditions of the Creative Commons Attribution (CC BY) license (http://creativecommons.org/licenses/by/4.0/). 